\title{
Biofilm formation of Salmonella species isolated from fresh cabbage and spinach
}

\author{
*11 ISOKEN H. IGBINOSA \\ ${ }^{I}$ Applied and Environmental Microbiology Research Group (AEMREG), Department of Biochemistry and Microbiology, University of Fort \\ Hare, Private Bag X1314, Alice 5700, South Africa \\ Department of Environmental Management and Toxicology, University of Benin, Private Mail Bag 1154, Benin City 300001, Nigeria \\ . Phone: $+27(0) 724036601,+2348131556897$
}

KEYWORDS: Public health, risk factor, antibiotic resistant, food safety, vegetables

\begin{abstract}
The aim of the study was to isolate Salmonella from fresh cabbage and spinach vegetables, determine antimicrobial resistance and biofilm formation of the isolates. Spinach and cabbage farm vegetables were found to harbour Salmonella. A total of eighty-two Salmonella isolates were recovered from both vegetables and subjected to antimicrobial reactions. Salmonella isolate showed sensitivity against the aminoglycoside and quinolones. Isolates from cabbage showed $\geq 80 \%$ susceptibility to nalidixic acid and ciprofloxacin and an average of $72 \%$ susceptibility was exhibited against gentamicin and ofloxacin. Also, isolates from spinach vegetable demonstrated excellent sensitivity against chloramphenicol (94\%), nalidixic acid $(90 \%)$ and ofloxacin $(82 \%)$. Variable resistant patterns was observed for tetracycline (58\%: 47\%), ampicillin (55.5\%: 31.4\%), erythromycin (58.1\%: 62.7\%), streptomycin (64.5\%: $76.5 \%)$, cephalothin (35.5\%: $39.2 \%)$ against isolates from cabbage and spinach respectively. The assessment of biofilm formation by Salmonella on microtitre plate showed that all Salmonella isolates were able to form biofilms. Isolates from cabbage were mainly strong producer $15(48.3 \%)$, while $11(35.5 \%)$ of the isolates were moderate producers and 6(16.1\%) weak producer. On the other hand, 28(54.9\%) of Salmonella isolates from spinach vegetable were moderate producer, $12(23.5 \%)$ weak producer and $11(21.5 \%)$ strong producer. The finding of this study shows that cabbage and spinach is potential host for the transmission of Salmonella to humans or other animals. The ability of the isolates to form biofilm reveals the potential of the isolates to persist on the vegetable and the pathogenic status of the isolates as well as ability to resist antimicrobial chemotherapy. @ JASEM
\end{abstract}

\section{http://dx.doi.org/10.4314/jasem.v19i1.6}

\section{Introduction}

Fresh vegetables are fundamental components of the human diet and there is considerable evidence of the health and nutritional benefits associated with the consumption of fresh vegetables. This has led to significant rise in the demand of fresh produce, changes in life styles and major shifts in consumption trends (Abadias et al., 2008; Tang et al., 2012).Vegetables can become contaminated with microorganisms capable of causing human diseases while still on the fields (Mukherjee et al., 2006). Bacteria such as Clostridium botulinum, Bacillus cereus and Listeria monocytogenes capable of causing disease, are normal inhabitants of many soils, while Salmonella, Shigella, Escherichia coli and Campylobacter which reside in the intestinal tracts of humans and animals, are more likely to contaminate raw vegetables through contact with faeces, sewage, untreated irrigation water or surface water (Cliver, 1997; Speer, 1997). Fresh farm produce can be a vehicle for the transmission of bacterial, parasitic and viral pathogens capable of causing human illness. There is documented evidence of raw vegetables harbouring potential food-borne pathogens, which can become contaminated while growing or during harvesting, post-harvest, handling, or distribution (Mukherjee et al., 2006; Abadias et al., 2008).

Bacterial pathogens continue to be a major contributor to produce-associated food-borne illnesses (Berger et al., 2010).The incidence and frequency of foodborne outbreaks caused by contaminated fresh vegetables is on the increase (De Roever, 1998; Wegener et al., 2003; Raufu et al., 2014). Salmonella is one of the pathogen most frequently linked to consumption of fruit and vegetables (Sivapalasingam et al., 2004). Several outbreaks of salmonellosis have been traced to contaminated fresh fruits and vegetables (Salleh $e t$ al., 2003; Berger et al., 2010). A wide spectrum of produce vehicles have been associated with Salmonella infections (Berger et al., 2010). The factors influencing the increase in salmonellosis due to vegetables are changes in agricultural practices, eating habits and increases in the worldwide commerce of fresh produce (Collins, 1997; Raufu et al., 2014).

Reports has shown that fresh spinach grown in three Californian countries were the source of microbial contamination that led to food-borne outbreak affecting 26 US states which resulted in about 200 
cases of illness, including some of haemolytic uremic syndrome and resulted in three deaths (FDA, 2006; Abadias et al., 2008). The consumption of fresh fruit and vegetables might therefore pose a food safety risk because they are susceptible to contamination by faecal material on the farm (Mukherjee et al., 2004; Abadias et al., 2008).

In present times, bacterial biofilms have been more linked to food safety issues globally. Biofilm is formed when bacterial cells attach to one another and stick on to a contact surface. Biofilm are hazardous as they can become a persistence source of contamination (Houdt and Michiels, 2010). The existence of pathogenic organisms in biofilms has been linked to foodborne illness outbreaks in cantaloupe melons, apples, and leafy greens (Annous et al., 2009). They are capable of adhering to plant surfaces and forcefully infect the plants interior (Schikora et al., 2012). Bacteria living within biofilms can exhibit 1000 times more resistance to antimicrobials than their planktonic peers. The close proximity of these bacteria within biofilm community enhances gene transfer; resulting in increased genetic diversity of antimicrobial resistance. Once biofilm forms on fresh produce surface, they not only can cause cross contamination to other food produce or processing equipment surfaces in industry, they also result in a potent health hazard to consumers (Tang et al., 2012).

As food is largely the vehicle for the transmission of Salmonella to humans it is desirable that all data on contamination of the various food types are available for analysis (Duggan et al., 2012). As a result of the serious implications from the consumption of contaminated vegetables, this work aimed at investigating Salmonella contamination of two major vegetables grown in Alice, Eastern Cape Province of South Africa, to determine their antibiotic resistance pattern as well as the adherence and pathogenic status of Salmonella.

\section{MATERIALS AND METHODS}

Sample collection: Twenty samples of fresh farm vegetables were collected from a vegetable farm in Eastern Cape Province of South Africa. Samples were kept in separate sterile plastic bags, and placed in a cooler with frozen gel packs and transport to the laboratory on the same day of collection for isolation and identification of Salmonella. Ten samples each of spinach and cabbage vegetables were collected.

Sample preparation: The method of Selleh et al. (2003) was used for the preparation of samples with modification. Briefly, the vegetables were placed on a working bench in aseptical environment and carefully separated. The separated parts were placed in a stomaching bag containing $225 \mathrm{~mL}$ of buffered peptone water (BPW) and incubated at $37{ }^{\circ} \mathrm{C}$ overnight.

Salmonella isolation and identification: One hundred millilitres of the pre-enriched samples was inoculated into $10 \mathrm{~mL}$ of Rappaport Vassiliadis Broth, (Merck) and $9 \mathrm{ml}$ of Mannitol Selenite Cystine Broth (Oxoid) and incubated for $24 \mathrm{~h}$ at $42{ }^{\circ} \mathrm{C}$ and $37{ }^{\circ} \mathrm{C}$ respectively. A loopful from each of the enriched broths were streaked onto Hektoen Enteric Agar (HEK) (Merck), Salmonella-Shigella Agar (Merck) and Xylose Lysine Deoxycholate Agar (XLD) (Merck), Agar plates were incubated at $37{ }^{\circ} \mathrm{C}$ for 18 to $24 \mathrm{~h}$. About 5 characteristic colonies of Salmonella were randomly picked from each plate and inoculated into Triple Sugar Iron Agar (TSA) (Merck) and Lysine Iron Agar (LIA) (Merck) slants. Each culture showing presumptive-positive TSI and LIA results were maintained on Tryptone Soya Agar (TSA)(Merck) (Salleh et al., 2003; Lertworapreecha et al., 2013).Gram reaction and oxidase test were carried out on the presumptive isolates. Suspected Salmonella colonies were confirmed by biochemical reactions using Analytical Profile Index (API) 20E strips (bioMérieux, Marcy-L’Étoile France).

Antimicrobial Susceptibility Testing: All isolates were tested for 12 antimicrobial drugs. Antibiotic disks were purchased from Mast Diagnostics (Mast Group Merseyside UK). The antibiotics used are as listed in Table 1. Isolates were sub-cultured on nutrient agar plates incubated for $24 \mathrm{~h}$ at $37{ }^{\circ} \mathrm{C}$. Colonies were picked from the agar plates, and suspended in normal saline $(0.85 \% \mathrm{w} / \mathrm{v})$, and the density of the suspension was adjusted to 0.5 McFarland standard. The bacterialsuspension was spread on the Mueller Hinton agar plates using a sterile swab stick, allowed to dry, and impregnated with antibiotic disk (Igbinosa et al., 2013). Plates were incubated at $37{ }^{\circ} \mathrm{C}$ for $24 \mathrm{~h}$. Diameters of the zones of inhibition were measured and interpreted, as susceptible, intermediate or resistant according to the Clinical Laboratory Standard Institute guidelines (CLSI 2006).

Biofilm Formation Assay: Quantitatively, biofilm formation among Salmonella isolates was assessed using microtitre plate method as described by Igbinosa et al. (2013). Flat bottomed 96 wells microtiter plates were dispensed with $200 \mu \mathrm{L}$ of Tryptone Soy Broth (TSB) and inoculated with $20 \mu \mathrm{L}$ of Salmonella isolates grown overnight and standardized to $0.5 \mathrm{McF}$ arland standards. Plates were incubated at $37{ }^{\circ} \mathrm{C}$ for $24 \mathrm{~h}$. Contents of each well were discarded and washed with sterile phosphatebuffered saline (PBS). Wells were allowed to air dry and stained with $200 \mu \mathrm{L}$ of $1 \%$ crystal violet for 30 min. The wells were carefully washed with distilled water to remove the excess stain. Plates were allowed to dry at room temperature. Dye bound to adherent 
cells was resolubilized with $150 \mu \mathrm{L}$ of absolute ethanol. Microplate reader (Synergy mx Biotek, USA) was used to read the plates at $570 \mathrm{~nm}$ wavelength. Average optical density (OD) of each duplicate result was taken including positive and negative controls. Isolates were categorized as non- biofilm producer $(\mathrm{ODi}<\mathrm{ODc})$, weak $(\mathrm{ODc}<\mathrm{ODi}<$ $0.1)$, moderate $(\mathrm{ODi}=0.1<0.12)$ and strong $(\mathrm{ODi}>$ 0.12 ) producers according to the modified methods of (Cevahir et al., 2008).

Table 1: List of antimicrobial used in the study

\begin{tabular}{llll}
\hline $\begin{array}{l}\text { Antibiotics } \\
\text { code }\end{array}$ & Antibiotics & Disk content & Antibiotic class \\
\hline TET & Tetracycline & $10 \mu \mathrm{g}$ & Tetracyclines \\
CHL & Chloramphenicol & $30 \mu \mathrm{g}$ & Phenicols \\
AMP & Ampicillin & $25 \mu \mathrm{g}$ & Penicillins \\
CIP & Ciprofloxacin & $5 \mu \mathrm{g}$ & Fluoroquinolones \\
GEN & Gentamicin & $10 \mu \mathrm{g}$ & Aminoglycosides \\
NAL & Nalidixic acid & $30 \mu \mathrm{g}$ & Quinolones \\
CEP & Cephalothin & $30 \mu \mathrm{g}$ & Cephalosporins \\
& & & (First generation) \\
STR & Streptomycin & $10 \mu \mathrm{g}$ & Aminoglycosides \\
TXM & Trimethoprim- & $25 \mu \mathrm{g}$ & Sulfonamides \\
& sulfamethoxazole & & \\
OFL & Ofloxacin & $5 \mu \mathrm{g}$ & Fluoroquinolones \\
ERY & Erythromycin & $15 \mu \mathrm{g}$ & Macrolides \\
VAN & Vancomycin & $30 \mu \mathrm{g}$ & Glycopeptide \\
\hline
\end{tabular}

\section{RESULTS AND DISCUSSION}

Salmonella is an important food-borne pathogen and its prevalence in fresh food poses a threat to human. The increase in demand and consumption of raw vegetables has resulted in a rise in food-borne related illnesses and outbreaks. Fresh vegetable have been reported to anchor potential food-borne pathogens including Salmonella (Harris et al., 2003; CDC, 2009).

In the study, spinach and cabbage farm vegetables were found to harbour Salmonella. Thirty-one (31) Salmonella isolates were isolated from cabbage vegetables while fifty-one (51) Salmonella isolates were isolated from spinach vegetables. The incidence and predominance of Salmonella in green leafy vegetables including lettuce and cabbage has been documented (Nillian et al., 2011).This is also in agreement with the findings of Chia et al. (2007) where leafy vegetables might permit more surface attachment that contribute to the high rate of Salmonella survival.These vegetables are top soil creeper hence soil may be a potential source of contamination especially if animal waste have been used as fertilizer (Nillian et al., 2011). Animal waste such as fresh faeces or human faeces from incompletely discomposed sludge from wastewater system when used as fertilizer could result to a primary source of contamination of the farm vegetables. When such fertilizers are applied to the soil, any contact or closest proximity of these farm vegetables to soil leads to contamination of the vegetable. In contrast, water is likely to be an important source of contamination of farm produce. Use of untreated wastewater for irrigation or irrigation water from a contaminated source is a major contributing factor to contamination. Improperly treated wastewater effluent disposed to fresh water system is a contributing source of contaminant to the river, and as such could contaminate farm vegetable when such water body is used as a source of irrigation to farm produce. Research has shown uptake and internalization of $E$. coli $\mathrm{O} 157: \mathrm{H} 7$ in spinach leaves after contaminated water was used for irrigation on the leaves (Mitra et al., 2009; Berger et al., 2010), thereby highlighting the potential risk associated with use of contaminated irrigation water.

During the cultivation stage, pathogenic organisms can establish themselves on growing crops. The risk can be enlarged after harvest either by further direct contamination or by proliferation of existing pathogen populations during processing and post harvest handling activities (Berger et al., 2010). Generally, Salmonella infection is self-limiting, however when symptoms persist, antimicrobial therapy is used. Hence the antimicrobial susceptibility of the isolates was carried out. The isolates showed diverse susceptibility profiles against the antibiotics under studied. Multiple antibiotic resistances were found against different classes of antibiotics; all the same, Salmonella isolate showed sensitivity against the aminoglycoside and quinolones (Table 2). Isolates from cabbage showed $\geq 80 \%$ susceptibility to nalidixic acid and ciprofloxacin while an average of $72 \%$ susceptibility was exhibited against gentamicin and ofloxacin. On the other hand, isolates from spinach vegetable demonstrated excellent sensitivity against chloramphenicol (94\%), nalidixic acid (90\%) and ofloxacin (82\%). All Salmonella isolates from both sources were absolutely (100\%) resistant to vancomycin, 51\% resistant to trimethoprim-sulfamethoxazole, whereas variable resistance patterns was observed for tetracycline (58\%: 47\%), ampicillin (55.5\%: $31.4 \%)$, erythromycin $(58.1 \%: 62.7 \%)$, streptomycin $(64.5 \%$ : 76.5\%), cephalothin (35.5\%: $39.2 \%)$ against isolates from cabbage and spinach respectively (Table 2). The isolates had a similar trend of 
antibiotic phenotypes suggesting a common source of contamination, however further molecular and epidemiological characterization is required to determine the linkage in source of contamination.

Table 2: Antibiotic susceptibility profile of Salmonella isolated from vegetable sources

\begin{tabular}{|c|c|c|c|c|c|c|}
\hline \multirow[t]{2}{*}{ Antibiotics } & \multicolumn{3}{|c|}{ Cabbage $(n=31)$} & \multicolumn{3}{|c|}{ Spinach $(n=51)$} \\
\hline & $\mathrm{S}(\%)$ & $\mathrm{I}(\%)$ & $\mathrm{R}(\%)$ & $\mathrm{S}(\%)$ & $\mathrm{I}(\%)$ & $\mathrm{R}(\%)$ \\
\hline Tetracycline & $5(16.1)$ & $8(25.8)$ & $18(58)$ & $17(33.3)$ & $10(19.6)$ & $24(47)$ \\
\hline Chloramphenicol & $24(77)$ & $6(19.3)$ & $1(3.2)$ & $48(94.1)$ & $3(5.9)$ & $0(0)$ \\
\hline Ampicillin & $14(45.2)$ & $0(0)$ & $17(55.5)$ & $30(58.8)$ & $5(9.8)$ & $16(31.4)$ \\
\hline Ciprofloxacin & $29(93.5)$ & $2(6.5)$ & $0(0)$ & $38(74.5)$ & $6(11.8)$ & $7(13.7)$ \\
\hline Gentamicin & $22(71)$ & $9(29.0)$ & $0(0)$ & $40(78.4)$ & $11(21.6)$ & $0(0)$ \\
\hline Nalidixic acid & $25(80.7)$ & $6(19.4)$ & $0(0)$ & $46(90.2)$ & $2(3.9)$ & $3(5.9)$ \\
\hline Cephalothin & $13(41.9)$ & $7(22.6)$ & $11(35.5)$ & $11(21.6)$ & $10(19.6)$ & $20(39.2)$ \\
\hline Streptomycin & $20(64.5)$ & $5(16.1)$ & $6(19.4)$ & $39(76.5)$ & $22(3.9)$ & $10(19.6)$ \\
\hline $\begin{array}{l}\text { Trimethoprim- } \\
\text { sulfamethoxazole }\end{array}$ & $10(32.3)$ & $5(16.1)$ & $16(51.3)$ & $18(35.3)$ & $7(13.7)$ & $26(51)$ \\
\hline Ofloxacin & $23(74.2)$ & $6(19.4)$ & $2(6.5)$ & $42(82.4)$ & $4(7.8)$ & $5(9.8)$ \\
\hline Erythromycin & $9(29.0)$ & $4(12.9)$ & $18(58.1)$ & $10(19.6)$ & $9(17.6)$ & $32(62.7)$ \\
\hline Vancomycin & $0(0)$ & $0(0)$ & $31(100)$ & $0(0)$ & $0(0)$ & $51(100)$ \\
\hline
\end{tabular}

Key: $\mathrm{S}=$ susceptible, $\mathrm{I}=$ intermediate, $\mathrm{R}=$ resistance

Several studies have documented high resistance of salmonella to the tetracyclines (Yoke-Kqueen et al., 2008; Learn-Han et al., 2009), which is in agreement with the result obtained in this study. The high resistance phenotypes rate of tetracycline observed in the study could be as a result of the use of tetracycline in food animal production which has led to worldwide spread of tetracycline resistance observed in Salmonella isolates (White et al., 2001; Logue et al., 2003; Parveen et al., 2007). Thereby indicating longitudinal transfer of resistance genes between Salmonella isolates from animal-related sources to vegetable sources (Learn-Han et al., 2009). Salmonella isolates from cabbage vegetable were highly sensitive to the quinolones and fluoroquinolones antibiotics compared to isolates from spinach vegetable. The absence of resistance to the fluoroquinolones by salmonella serovars from vegetable in Nigeria has been documented (Raufu et al., 2014). Salmonella resistance to the fluoroquinolones (ciprofloxacin) is of great concern to public health as invasive forms of salmonellosis are treated with these compounds (Gordon, 2000; White et al., 2001; Learn-Han et al., 2009).

Although variable sensitivity with chloramphenicol was observed against isolates form both sources, however, the low resistance rate might be attributed to the controlled use of chloramphenicol due to the concern of its severe side effects which indirectly increases the efficiency of the antibiotic (Kambal, 1996; Learn-Han et al., 2009).The occurrence of multi-drug resistance Salmonella from fresh vegetables is of global health concern as this could led to major healthcare challenge since multi-drug resistance hinder the possibility of therapeutic treatments. The health benefits of consumption of vegetables has led to significant rise of eating of vegetables among the pregnant, young, old, and ill challenged individuals thereby leading to higher risk of infection among these group of consumers. Hence this is vital in the risk assessment and management of the consumption of vegetables.

A number of studies have shown that Salmonella spp are capable of adhering and forming biofilms on diverse surfaces including metal, glass and rubber surfaces (Hood and Zottola, 1997; Joseph et al., 2001; Stepanovic'et al., 2004). The assessment of biofilm formation by Salmonella on microtitre plate showed that all Salmonella isolates were able to form biofilms. The bacteria under study were able to form biofilm on microtiter plate potentiating its ability to form biofilm on different surfaces. Isolates from cabbage were mainly strong producer $15(48.3 \%)$, while $11(35.5 \%)$ of the isolates were moderate producers and $6(16.1 \%)$ weak producer as shown in Fig 1. On the other hand, 28(54.9\%) of Salmonella isolates from spinach vegetable were moderate producer, $12(23.5 \%)$ weak producer and $11(21.5 \%)$ strong producer.

Ability of Salmonella to form biofilm even at minimum nutrient medium has been demonstrated (Stepanovic'et al., 2004). Also the efficiency of TSB in Salmonella has also been reported. The biofilm formation of the Salmonella isolates observed in the study may have been enhanced by favourable growth media, however literature has shown that Salmonella is able to form biofilm even at minimal nutrient medium.The study reveals that Salmonella isolated from vegetable is able to form biofilms. A correlation between the capacity to produce biofilms and the attachment to leaves, with Salmonella showing the efficient adhesion to lettuce leaves has been documented (Patel and Sharma, 2010; Schikora et al., 2012). Hence, the biofilm forming ability demonstrated by these Salmonella isolates reveals the pathogenic status of the isolates. Bacteria can use multiple hosts as channel to human or other animals. 
Salmonella is capable of using plant as an alternative route to human; therefore, the consumption of contaminated vegetables poses a health risk to humans.

Management of growing conditions are essential in preventing the contamination of fresh farm produce by human pathogens. Preventive strategies should be employed to avert the contamination of farm vegetables, which include good agricultural practices. Strategies similar to hazard analysis and critical control point programs, which have been effectively used in other areas of food production, if scientifically applied to animal production industries, may improve food safety.

Acknowledgement: The author thanks University of Fort Hare for financial support.

\section{REFERENCE}

Abadias M., Usall J., Anguera M., Solsona C. and Viñas I. (2008). Microbiological quality of fresh, minimally-processed fruit and vegetables, and sprouts from retail establishments. Int. J. Food Microbiol. 123, 121-129.

Annous B. A., Fratamico P. M., and Smith, J. L. (2009). Scientific status summary. J. Food Sci. 74, 24-37.

Berger C.N., Sodha S.V., Shaw R.K., Griffin P.M., Pink D., Hand P. and Frankel G. (2010). Fresh fruit and vegetables as vehicles for the transmission of human pathogens. Environ. Microbiol. 12, 2385-2397.

CDC (2009). Surveillance for food-borne disease outbreaks-United States, Centers for Disease Control and Prevention. Morb Mortal Wkly Rep 58:609-15.

Cevahir N., Demir M., Kaleli I.,Gurbuz M. and Tikvesli S. (2008). Evaluation of biofilm production, gelatinase activity, and mannoseresistant hemagglutination in Acinetobacter baumannii strains. J. Microbiol. Immunol. Infection. 41, 513-518.

Chia L.L., Cheng H. C., Chishih C., Yhu C. H., Tzou Y. L. and Jonathan T. O. (2007). A multiplex polymerase chain reaction method for rapid identification of Citrobacter freundii and Salmonella species, including Salmonella typhi. J. Microbiol. Immunol. Infect. 40, 222-226.

Clinical and Laboratory Standard Institute (CLSI) (2006). Performance standards for antimicrobial susceptibility testing; sixteenth informational supplement. Clinical and Laboratory Standards Institute, 7th edition, Wayne, Pa, USA. 2006; M100-S16, 26:pp. 15-130
Cliver D.O. (1997). Food-borne viruses. In: Doyle MP, Beuchat LR, Montville TJ (eds.) Food Microbiology: Fundamentals and Frontiers, p. 437-446. Washington, DC, American Society for Microbiology.

Collins J.E. (1997). Impact of changing consumer lifestyles on the emergence/re-emergence of food-borne pathogens. Emerg. Infect. Dis. 3, 471-479.

De Roever C (1998). Microbiology safety evaluation and recommendations on fresh produce. Food Control 9, 321-347.

Duggan S., Jordan E., Gutierrez M., Barrett G., O'Brien T., Hand D., Kenny K., Fanning J., Leonard N. and Egan J. (2012). Salmonella in meats, water, fruit and vegetables as disclosed from testing undertaken by Food Business Operators in Ireland from 2005 to 2009. Irish Vet. J. 65, 1-7.

Harris L.J., Farber J.N., Beuchat L.R., Parish M.E., Suslow T.V., Garrett E.H. and Busta F.F. (2003). Outbreaks associated with fresh produce: incidence, growth, and survival of pathogens in fresh and fresh cut produce. Comp. Rev Food Sci Food Safety 2, 78-141.

FDA (Food and Drug Administration, USA), 2006.Spinach and E. coli outbreak. URL:

http://www.fda.gov/oc/opacom/hottopics/spinach.htl.

Gordon, D. 2000. Ceftriaxone-resistant Salmonella infection from antibiotic-treated cattle. Gastroenterol. 119: 3.

Hood S.K. and Zottola E.A. (1997). Adherence to stainless steel food-borne microorganisms during growth in model food systems. Inter. J. Food Microbiol. 37, 145 -153.

Houdt R. V. and Michiels, C. (2010). Biofilm formation and the food industry, a focus on the bacterial outer surface. J. Appl. Microbiol. 109: 1117-1131.

Igbinosa I.H., Chigor V.N., Igbinosa E.O., Obi L.C. and Okoh A.I. (2013). Antibiogram, adhesive characteristics, and incidence of class 1 Integron in Aeromonas species isolated from two South African rivers. BioMed Research Inter. Article ID 127570,8 pages

Joseph B., Otta S.K., Karunasagar I. and Karunasagar I. (2001). Biofilm formation by Salmonella spp. on food contact surfaces and their sensitivity to sanitizers. Inter. J. Food Microbiol. 64, 367-372. 
Kambal A.M. (1996). Antimicrobial susceptibility and serogroups of Salmonella isolates from

Riyadh, Saudi Arabia. Inter. J. Antimicrobial Agents 7, 265-269.

Learn-Han L., Yoke-Kqueen C., Shiran M.S., Sabrina S., Noor Zaleha A.S., Sim J.H., Chai-Hoon, K. and Son R. (2009). Molecular characterization and antimicrobial resistance profiling of Salmonella enteric subsp. Enteric isolated from 'Selom' (Oenanthest olonifera). Inter. Food Res. J. 16, 191-202.

Lertworapreecha M., Sutthimusik S, and Tontikapong K. (2013). Antimicrobial resistance in Salmonella enterica isolated from pork, chicken, and vegetables in Southern Thailand. Jundishapur J. Microbiol. 6, 36-41.

Logue C. M., Sherwood J. S., Olah P. A., Elijah L. M. and Dockter M. R. (2003). The incidence of antimicrobial-resistant Salmonella spp. on freshly processed poultry from US Midwestern processing plants. J. Appl. Microbiol. 94, 16-24.

Mitra R., Cuesta-Alonso E., Wayadande A., Talley J., Gilliland S., and Fletcher J. (2009). Effect of route of introduction and host cultivar on the colonization, internalization, and movement of the human pathogen Escherichia coli O157:H7 in spinach. J. Food Prot. 72, 1521-1530.

Mukherjee A., Speh D., Jones A.T., Buesing K.M. and Diez-Gonzalez F. (2006). Longitudinal microbiological survey of fresh produce grown by farmers in the upper Midwest. J. Food Protect. 69, 1928-1936.

Nillian E., Ching C.L., Fung P.C., Robin T., Anyi U., Chilek T.Z.T., Radu S. and Nishibuchi M. (2011). Simultaneous detection of Salmonella spp., Salmonella enteritidis and Salmonella typhimurium in raw salad vegetables and vegetarian burger patties. Food and Nutrition Sci. 2, 1077-1081.

Parveen S., Taabodi M., Schwarz J.G., Oscar T.P., Harter-Dennis J, and White D.G. (2007). Prevalence and antimicrobial resistance of Salmonella recovered from processed poultry J. Food Protect. 70, 2466-2472.

Patel J. and Sharma M. (2010). Differences in attachment of Salmonella enteric serovars to cabbage and lettuce leaves. Int. J. Food Microbiol. 139, 41-47.

Raufu I.A., Zongur L., Lawan F.A., Bello H.S., Adamu M.S., Ameh J.A. and Ambali A.G. (2014). Prevalence and antimicrobial profiles of Salmonella serovars from vegetables in
Maiduguri, North Eastern Nigeria. Sokoto J. Vet. Sci. 12, 23-28.

Salleh N.A., Rusul G., Hassan Z., Reezal A., Isa S.H., Nishibuchi M. and Radu S. (2003). Incidence of Salmonella spp. in raw vegetables in Selangor, Malaysia. Food Control 14, 475479.

Schikora A., Garcia A.V. and Hirt H. (2012). Plants as alternative hosts for Salmonella. Trends in Plant Sci. 17, 245-249.

Sivapalasingam S., Friedman C.R., Cohen L. and Tauxe R.V. (2004). Fresh produce: a growing cause of outbreaks of foodborne illness in the United States, 1973 through 1997. J. Food Protect. 67, 2342-2353.

Speer C.A. (1997). Protozoan parasites acquired from food and water. In: Doyle MP, Beuchat LR, Montville TJ (eds.) Food Microbiology: Fundamentals and Frontiers, p. 478-493 Washington, DC, American Society for Microbiology.

Stepanovic' S., C'irkovic' I., Ranin L and Svabic'vlahovic' M. (2004). Biofilm formation by Salmonella spp. and Listeria monocytogenes on plastic surface. Letters Applied Microbiol. 38, 428-432.

Tang P. L., Pui C. F., Wong W. C., Noorlis A. and Son R. (2012). Biofilm forming ability and time course study of growth of Salmonella typhi on fresh produce surfaces. Inter. Food Res. J. 19, 71-76.

Wegener H.C., Hald T., Wong L., D, Madsen M., Korsgaard N., Bager F., Gerner-Smidt P. and Molbak K. (2003). Salmonella control programs in Denmark. Emerging Infect. Dis. 9, 774-780.

White D. G., Zhao S., Sudler R., Ayers S., Friedman S., Chen S., McDermott P. F., McDermott S., Wagner D. D. and Meng. J. (2001). The isolation of antibiotic-resistant Salmonella from retail ground meats. N. Engl. J. Med. 345, 1147-1154.

Yoke-Kqueen C., Learn-Han L., Noorzaleha A.S., Son R., Sabrina S., Jiun-Horng S. and ChaiHoon K. (2008). Characterization of multipleantimicrobial resistant Salmonella enteric subsp. Enteric isolated from indigenous vegetables and poultry in Malaysia. Letters Appl. Microbiol. 46, 318-324. 